Abstracta Iranica Abstracta Iranica

Revue bibliographique pour le domaine irano-aryen

Volume 28 | 2007

Comptes rendus des publications de 2005

\title{
Amir Khusraw. The Poet of Sultans and Sufis. Oxford, Oneworld, 2005, ix-140 p., ills. (Série: Makers of the Muslim World, ed. Patricia Crone)
}

Anna Livia Beelaert

\section{(2) OpenEdition}

1 Journals

Édition électronique

URL : http://journals.openedition.org/abstractairanica/21171

DOI : 10.4000/abstractairanica.21171

ISSN : 1961-960X

Éditeur :

CNRS (UMR 7528 Mondes iraniens et indiens), Éditions de l'IFRI

\section{Édition imprimée}

Date de publication : 15 mai 2007

ISSN : 0240-8910

Référence électronique

Anna Livia Beelaert, «Amir Khusraw. The Poet of Sultans and Sufis. Oxford, Oneworld, 2005, ix-140 p., ills. (Série: Makers of the Muslim World, ed. Patricia Crone) », Abstracta Iranica [En ligne], Volume 28 | 2007, document 353, mis en ligne le 18 septembre 2007, consulté le 25 septembre 2020. URL : http:// journals.openedition.org/abstractairanica/21171; DOI : https://doi.org/10.4000/abstractairanica. 21171

Ce document a été généré automatiquement le 25 septembre 2020.

Tous droits réservés 


\title{
Amir Khusraw. The Poet of Sultans and Sufis. Oxford, Oneworld, 2005, ix-140 p., ills. (Série: Makers of the Muslim World, ed. Patricia Crone)
}

\author{
Anna Livia Beelaert
}

Ce petit livre sur un des poètes persans majeurs (651/1253-725/1325), la première monographie qui lui ait été consacrée depuis vingt ans, est publié dans une série qui n'est pas en premier lieu destinée aux spécialistes. C'est donc dans ce cadre qu'on peut comprendre qu'aucune des assertions de l'A. ne soit explicitement fondée sur des recherches antérieures (bien que le livre soit pourvu d'une bibliographie) et qu'aucune des nombreuses citations de poèmes ne soit accompagnée d'une référence exacte. Les iranistes restent donc sur leur faim, ils ne peuvent pas, par exemple s'assurer qui sont les “scholars" (p. 28) qui ont établi définitivement qu'Amīr Hosrow n'est pas l'auteur de l'Afdal al-fawā'ed (un livre du genre des malfüzāt, concernant son maitre Nizāām al-Dīn Awliyā', livre dont d'ailleurs la paternité littéraire a toujours été contestée); ils ne peuvent non plus situer le texte original de tel ou tel ǵazal dans la vaste œuvre lyrique d'un poète qui a rédigé cinq dīvāns. S. Sharma en tout cas montre l'importance de cet auteur, dans l'Inde de son temps tout comme dans celle d'aujourd'hui, où on continue, dans les séances de qavvālì, de chanter ses poèmes, aussi bien ceux en persan que ceux en "hendavi”" (bien que ces derniers de toute apparence lui sont seulement attribués). Le livre comprend en annexe deux traductions nouvelles : la notice sur Amīr Hुosrow tirée du Siyar al-awliyā' d'Amīr Hुord (m. 770/1369) (pp. 93-98) et la quatrième histoire raccontée au roi Bahrām dans le mațnavī, Hašt behešt (pp. 99-126). 
INDEX

Thèmes : 11.1.1. Littérature persane classique

\section{AUTEURS}

ANNA LIVIA BEELAERT

Université libre de Bruxelles 